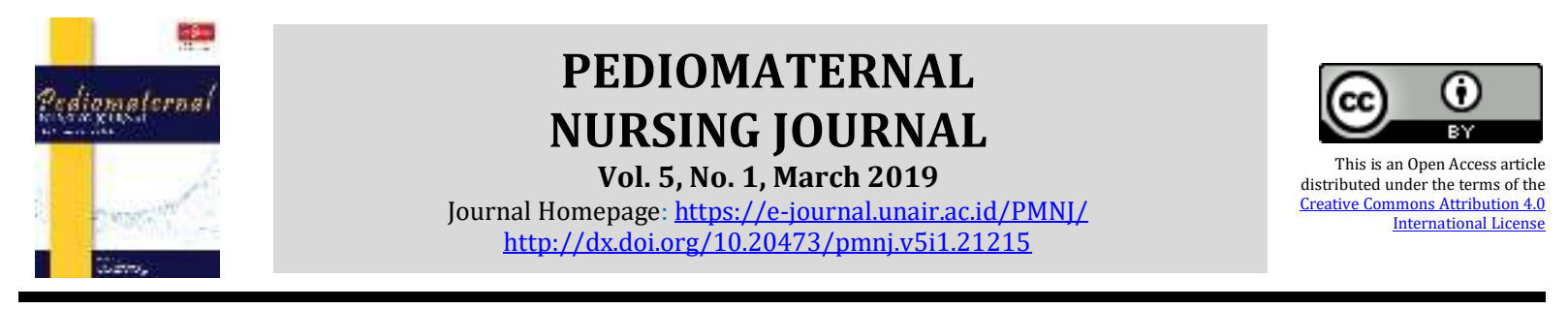

Scientific Editorial

\title{
EDITORIAL
}

\section{Menilik Kesehatan dan Gangguan Reproduksi Pada Perempuan}

\author{
Ni Ketut Alit Armini, S. Kp., M. Kes \\ Departemen Maternitas dan Anak, Fakultas Keperawatan, Universitas Airlangga, \\ Kampus C Mulyorejo, Surabaya, Indonesia, Telp. (031) 5913257, 5913754 Fax. (031) \\ 5913257, email: nk.alita@fkp.unair.ac.id
}

Bangsa yang sehat dan berdaya saing tinggi terlahir dari generasi yang sehat jiwa, raga, spiritual dan sosial. Perempuan mempunyai potensi sangat besar dalam upaya memajukan bangsa. Potensi tersebut terlihat pada fitrah perempuan ketika mengandung dan melahirkan anak-anak bangsa, membesarkan dan mendidik anak dengan penuh perhatian dan kasih sayang, mengantarkan anak menjelang dewasa untuk memasuki kehidupan bermasyarakat yang baik, serta senantiasa mendoakan kebaikan anak-anaknya sampai akhir hayat. Besarnya potensi yang dimiliki oleh perempuan, maka kesehatan perempuan seharusnya dijaga sepanjang siklus kehidupan sejak dari dalam rahim dan lahir sampai akhir hayat, mengingat kontribusi penting tugas reproduksi perempuan dalam prokreasi generasi penerus. Masalah kesehatan reproduksi perempuan, termasuk perencanaan kehamilan dan persalinan yang aman harus menjadi perhatian bersama, bukan hanya kaum perempuan saja karena hal ini akan berdampak luas dan menyangkut berbagai aspek kehidupan yang menjadi tolak ukur dalam pelayanan kesehatan.

Konteks yang positif, kesehatan reproduksi tidak hanya berarti terbebas dari penyakit atau gangguan selama proses reproduksi,tetapi kondisi ketika proses reproduksi tercapai dalam situasi kesehatan fisik, mental, dan sosial yang sempurna. Ini berarti bahwa manusia mempunyai kemampuan untuk bereproduksi, wanita dapat melalui masa kehamilan dan persalinan dengan aman, dan reproduksi memberi hasil yang positif juga yaitu bayi dapat hidup dan tumbuh dengan sehat. Pengertian ini juga mempunyai implikasi bahwa manusia dapat mengatur fertilitas mereka tanpa risiko mengalami gangguan kesehatan dan dapat mengalami seks yang aman.

Problem kesehatan reproduksi yang dialami para perempuan biasanya dikarenakan banyak faktor. Faktor yang bersifat internal terkait dengan persoalan pemahaman mengenai kesehatan reproduksi. Faktor yang bersifat ekternal bisanya merupakan faktor yang 
berhubungan dengan hal yang berada di luar kemampuan diri seperti lingkungan, pergaulanan, perkembangan teknologi informasi dan komunikasi, dan lain-lain. Pemahaman mengenai kesehatan reproduksi menyumbangkan begitu besar kontribusi persoalan-persoalan reproduksi. Perempuan dengan pemahaman tentu mengarahkan dirinya untuk menghindari resiko dan dampak negatif bagi diri, keluarga, dan lingkungannya.

Pelaksanaan Kesehatan Reproduksi dilaksanakan dengan menggunakan pendekatan siklus hidup (life-cycle approach) agar diperoleh sasaran tepat dengan memperhatikan hak reproduksi. Kesehatan reproduksi memiliki tiga komponen yaitu kemampuan prokreasi, mengatur dan menjaga tingkat kesuburan, dan menikmati kehidupan seksual secara bertanggung jawab. Tugas reproduksi perempuan terdiri dari Organ-organ yang berfungsi mendukung proses reproduksi manusia, mulai dari memproduksi ovom, berhubungan seksual, melindungi dan merawat janin selama hamil di dalam rahim, hingga melahirkan. Gangguan sistem reproduksi wanita karena kelainan organik, hormonal, maupun karena faktor perilaku tidak bisa dianggap sepele. Gangguan pada organ reproduksi wanita dapat meningkatkan risiko wanita untuk mengalami masalah fertilitas.

Menyimak masalah kesehatan dan penanganan gangguan reproduksi pada perempuan merupakan agenda sangat penting bagi semua pihak baik di lingkungan pendidikan, lingkup pelayanan, maupun di masyarakat. Perlu adanya lebih banyak telaah ilmiah tentang kesehatan reproduksi dan upaya mengembangkan kebijakankebijakan publik yang realistis menjawab tantangan permasalahan kesehatan reproduksi perempuan. 